УДК: 37.013

\title{
Bill DIMOPOULOS
}

Higher School of Pedagogical and

Technological Education, Greece, billdim2000@yahoo.gr

\section{THE VITALISTIC COMPONENTS OF THE NIETZSCHEAN MAN: SOCIETY, CULTURE, EDUCATION}

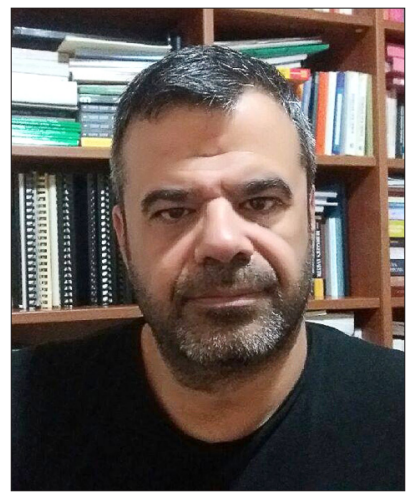

\begin{abstract}
What is life? - Life - that is:
Continually shedding something that wants to die?

Life - that is: being cruel and inexorable against anything that is growing weak and old in us, and not just in us.
\end{abstract}

Friedrich Nietzsche - The Gay Science

The nietzschean man is composed on the basis of life's attempt to realize the terror, the horror and the absurdity hiding in itself. In others words it concerns an extremely dangerous, tragic as well as uncertain demand fulfilled only by means of society, culture and education. As a consequence of this triple help emerges a new category of men called to struggle against the tragic content of existence. It's about a coming generation with "intrepidity of vision", which does not, however, have relations with the bloodthirsty barbarians. This is because its power does not deliver from the brutal force but from the intellectual ability to stand and transform the pain into representations justifying the world.

Keywords: life, genius, transformation, pain, terror, society, culture, education

The search of man in his ideal form leads to a creature of "metaphysical origin" and "metaphysical home" (Nietzsche, 2004: p. 67) that discloses the transcendental definitions existing in the core of the nietzschean anthropology. An anthropology that is requested to serve the highest undertaking of life itself - i.e. a "dark, driving power that insatiably thirsts for itself" (Nietzsche, 1997: p. 76) - which strives for the redemption from the "curse of the animal" (Nietzsche, 1997: p. 157). More precisely it is struggling to overcome the "unconsciousness of instinct" (Nietzsche, 1997: p. 158) in order to reach self - knowledge by means of a rare group of geniuses. This means that it is trying to draw out in the light of human consciousness all the breadth of the cosmic problematic or otherwise to bring us face to face with an excessively dangerous truth. A truth that discloses the "terror and horror of existence" (Nietzsche, 1966: p. 42), warns of the "ter- 
rible destructiveness of co-called world history as well as the cruelty of nature" (Nietzsche, 1966: p. 59) and presents the "primal and eternal suffering" as "the sole ground of the world" (Nietzsche, 1966: p. 45). It concerns a world seeming not only painful but also "absurd" (Nietzsche, 1966: p. 60) because within it we are subject to a meaningless as well as purposeless suffering proving that "existence and world are eternally justified as an aesthetic phenomenon" (Nietzsche, 1966: p. 52). This is so because "no one gives a human being his qualities: not God, not society, not his parents or ancestors, not he himself ... One is necessary, one is a piece of fate" (Nietzsche, 1990a: p. 64). In other words we seem like a "shadowy", "transient", "aimless" and "arbitrary" creature being thrown into "some out of the way corner of that universe" (Nietzsche, 1990b: p.79). A child of "chance and misery" (Nietzsche, 1966: p. 42) that the wise Silenus advised once: "What is the best of all is utterly beyond your reach: not to be born, not to be, to be nothing. But the second best for you is - to die soon". (Nietzsche, 1966: p. 42). Trying to avoid this possibility of abandonment and suicide Nietzsche searched for the men taking on the tragic content of existence. It concerns a generation with "intrepidity of vision" and a "heroic penchant for the tremendous" (Nietzsche, 1966: p. 26) which however has absolutely nothing to do with the bloodthirsty barbarians. This is because their power consists in the ability to endure - and not to cause - the pain. An ability regarded by Nietzsche as a sign of noble origin as well as a means of self - knowledge:

"Hierarchy is virtually determined by how deeply people can suffer ... Deep suffering makes us noble; It separates" (Nietzsche, 1998b: pp. 166-167)

"Only great pain, that long, slow pain that takes its time and in which we are burned, as it were, over green wood, forces us ... to descend into our ultimate depths" (Nietzsche, 2001: p. 6)

Concluding we remark that life's longing to know itself brings us face to face with a terrifying, horrible and illogical undertaking related only with a small minority of persons. An undertaking not only repulsive but also uncertain since nature is unable to ensure it by its own means. This is so because concerning Nietzsche: "Nature seems to be bent of squandering ... its expenditure is much larger than the income it procures" (Nietzsche, 1997: pp. 177 - 178). For this reason its human aim seems to appear by chance in his age "as a hermit, or a wonderer who has lost his way and been left behind" (Nietzsche, 1997: p. 178). This very failing is covered by the socio/cultural factor described as a kind of "transfigured" (Nietzsche, 1997: p. 145) and "improved" (Nietzsche, 1997: p. 123) physis.

\section{The social field}

Focusing on the society we notice that it is presented as an institution fully differentiated from the trite approaches in order to become "the great trustee 
of life" (Nietzsche, 1968: p. 389). This is because in its utopic form it seems to categorize the individuals according to their degree of endurance against the cosmic suffering since "the most spiritual human beings find their happiness where others would find their destruction", namely, "in the labyrinth, in severity towards themselves and others, in attempting" (Nietzsche, 1990a: p. 188). So concerning Nietzsche: "In a better ordering of society the heavy work and exigencies of life will be apportioned to him who suffers least as a consequence of them, that is to say to the most insensible, and thus step by step up to him who is most sensitive to the most highly sublimated species of suffering and who therefore suffers even when life is alleviated to the greatest degree possible" (Nietzsche, 1996: pp. 168-169). It's about an ideal, based on the "pathos of distance" (Nietzsche, 1998b: p. 151) or otherwise on a sense of rareness and uniqueness which is necessary for the noble class to achieve its aims. That is because the heroic deeds require (Pearson, 1994: p. 51) feelings which transcend the ordinary, the everyday, and the utilitarian. In addition they presuppose an extraordinary kind of freedom dealing only with the minority since: "Independence is for the very few; it is a privilege of the strong" (Nietzsche, 2001: p. 30). It concerns a dividing privilege that nevertheless has to be accepted by the other individuals. That is because being unable to attain (Pearson, 1994: p. 55) greatness, they should at least serve it. But how is it possible for the vast majority to contribute to such a slavish service? The answer given by Nietzsche is devoid of any legitimacy springing from the concepts of equality and justice inasmuch as "the course of human affairs is determined by force, deception and injustice" (Nietzsche, 1997: p. 212). For this reason he ignored ostentatiously the necessity of a peaceful social contract (Nietzsche, 1994: p. 63) and attempted, by means of an "untenable naturalism" (Pearson, 1994: p. 41), to transfer the law of nature to the social field. In support of this transference Nietzsche clarified: "The order of castes, the supreme, the dominant law, is only the sanctioning of a natural order, a natural law of the first rank, over which no arbitrary caprice, no "modern idea" has any power" (Nietzsche, 1990a: p. 187). In this context he looked for a new kind of legitimacy moving "beyond good and evil". A supra-moral legitimacy being put in the service of power that asks and answers as follows: "What is good? - All that heightens the feeling of power, the will to power, power itself in man. What is bad? - All that proceeds from weakness. What is happiness? - The feeling that power increases" (Nietzsche, 1990a: p. 125). But while the genius plays a leading role in a world determined by the notions of strength and weakness he does not need to dominate others. This is so, because he incarnates a joyful and creative spirit without repressed impulse that has nothing to demonstrate. A generous and inspiring spirit that behaves as follows: "When an exceptional human being handles the mediocre more gently than he does himself or his equals, this is not mere po- 
liteness of the heart-it is simply his duty." (Nietzsche, 1990a: p. 189). On the contrary, it is usually weak people who need to control others in order to gain a sense of self - esteem and confidence; namely, the "bearers of decline" (Nietzsche, 1968: p. 461) who invented the instincts of "ressentiment", "cunning" and "canaille".

\section{The cultural field}

Having outlined his social vision Nietzsche ought subsequently to answer the following question: "Suppose a human being has thus put his ear, as it were, to the heart chamber of the world will and felt the roaring desire for existence pouring from there into all the veins of the world ... how could he fail to break suddenly?" (Nietzsche, 1966: p. 127). In other words how is it possible for him to realize the eternal pain "without denial of individual existence?" (Nietzsche, 1966: p. 127) This is so because "true knowledge, an insight into the horrible truth ... kills action; Action requires the veils of illusion" (Nietzsche, 1966: p. 60). And this very dire need is covered by the vital will inasmuch as: "It is an eternal phenomenon: the insatiable will always find a way to detain its creatures in life and compel them to live on, by means of an illusion spread over things. One is chained by the Socratic love of knowledge ... another is ensnared by art's seductive veil of beauty fluttering before his eyes; still another by the metaphysical comfort that beneath the whirl of phenomena eternal life flows on indestructibly ... These three stages of illusion are actually designed only for the more nobly formed natures, who actually feel profoundly the weight and burden of existence, and must be deluded by exquisite stimulants into forgetfulness of their displeasure. All that we call culture is made up of these stimulants; and, according to the proportion of the ingredients, we have either a dominantly Socratic or artistic or tragic culture" (Nietzsche, 1966: p. 110). On the basis of the above stimulants Nietzsche wonders: "Is there pessimism of strength? An intellectual predilection for the hard, gruesome, evil, problematic aspect of existence, prompted by well-being, by overflowing health, by the fullness of existence?" (Nietzsche, 1966: p. 17). The affirmative answer came from the third kind of culture created by the ancient Greeks and led through tragedy to the direct confrontation with the true nature of the world. This is so because it managed to express the pain and the horror symbolically as a drama depicting the death of the tragic hero. A drama plunging the spectator into the Dionysian depth of the world and at the same time emerging him to an apollonian redemptive surface since: "With the immense impact of the image, the concept, the ethical teaching, and the sympathetic emotion, the Apollonian tears man from his orgiastic self-annihilation and blinds him to the universality of the Dionysian process, deluding him into the belief that he is seeing a 
single image of the world" (Nietzsche, 1966: p. 128). It represents an image of highest aesthetic value where the art turns the "horrible" into "sublime" and the "nauseous" into "comic" (Nietzsche, 1966: p. 60) helping the spectator to face, accept and finally love his human fate; namely that "all that comes into being must be ready for a sorrowful end" (Nietzsche, 1966: p. 104). However, for this to happen he must take part in a long - lasting as well as painful ${ }^{1}$ process in which education plays the leading role.

\section{The educational field}

In this area the dominant element is the command "be yourself" (Nietzsche, 1997: p. 127) that - as we have already seen - is related with the demand of life to know its being. In other words it is directed to a small minority of people that Nature is unable to create by its own means. For this reason it searches for the help of education looking like a pregnant mother (Nietzsche, 2004: p. 67) dedicated to the "aristocratic nature of the spirit" (Nietzsche, 2004: p. 66). On the basis of the above role, pedagogy acquires a deep emotive character aiming at the direct and personal relation of children with nature that allows them to sense the "metaphysical oneness", the "persistence" and the "necessity of all things" (Nietzsche, 2004: p. 83). Trying to achieve it, the education of the first years focuses especially on the teaching of painting, dancing, playing and of fairytales. To the extent, however, that these very activities serve the life and not simply the needs of the underage innocence they seem to acquire a completely new meaning. In our estimation, this is so because: Firstly, the art is mainly related with the "aesthetic justification" (Nietzsche, 1966: p. 52) of existence and not simply with the personal expression and creation. Secondly, the play imitates the heraclitian aeon that constructs and destroys "in forever equal innocence" (Nietzsche, 1998a: p. 62). In particular it is referred to an ecstatic form of action resembling the childish "towers of sand at the seashore" (62); namely it creates and demolishes motivated by an aesthetic (Nietzsche, 1998a: pp. $62-63)$ - and not moral - predisposition. Thirdly, the dance is not foremost a kind of kinetic expression but a form of bodily identification with the "gospel of universal harmony" (Nietzsche, 1966: p. 37); i.e. the Dionysian cosmic rhythm. Fourthly, the contact with the world of fairytales constitutes the starting point of a course ending in the myth; namely in a powerful creation of Dionysian origin (Nietzsche, 1966: p. 131) that overcomes by far the character of a simple allegorical story. This is because it forms a "concentrated image of

${ }^{1}$ For the pedagogical value of pain and suffering see Hillesheim, Suffering and Self Cultivation: The case of Nietzsche, pp. 171 - 178, Rosenow, Nietzsche's Educational Dynamite, Educational Theory, pp. 307 - 316 and Hillesheim, Nietzschean Image of Self-Overcoming, pp. $211-215]$. 
the world" (Nietzsche, 1966: p. 135) that tries - when Reason and Science are unable - to transform the tragic aspect of life into happy - ending narratives.

Subsequently, in secondary education the concept of life is clearly evident in the content as well as the teaching of mother tongue and history. Starting from the first field Nietzsche tried to highlight the "living" (Nietzsche, 2004: p. 46) and "artistic" (Nietzsche, 2004: p. 44) ${ }^{1}$ character of the linguistic expression. In order for this to happen, the students have to come into close contact with the works of German classic authors (Nietzsche, 2004: p. 45) so as to be put "under the glass bell of good taste and rigorous linguistic discipline" (Nietzsche, 2004: p. 44). Furthermore, starting from the belief that the knowledge of history must serve (Nietzsche, 1997: pp. 66-67) life - and not the contrary - Nietzsche detected the value of the historical lesson in its ability to transform the past into life. It is an undertaking rendered workable not with the sterile memorization but with the activation of the "plastic power" (Nietzsche, 1997: p. 62) existing within the student that enables him to adopt the historical matter to his own needs.

Finally, at university the notion of life is detectable in the lessons of philosophy, art and Greek culture. So the teaching of philosophy should not be targeted to "what this or that philosopher has thought or not" (Nietzsche, 2004: p. 109) but to strengthen the ability for philosophizing. It's about an ability drawing its material from students' experiences and problems in order to reach the level of philosopher - educator (Nietzsche, 1997: p. xvii) who teaches not through his book but - through his actions and his own life. In addition, the academic teaching of art is related with the "advancement of the most important national art projects" (Nietzsche, 2004: pp. 109 - 110); namely the promotion of a (one of Wagnerian origin) musical drama capable of coping successfully with the dangers surrounding the German nation. In this context a peculiar conception of music stands out that is not connected with the human creation but with the ultimate demand of the cosmic Will; namely the "existence in sound" (Nietzsche, 1997: p. 240). Ending up, the students' contact with the world of the Ancient Greek culture is fully differentiated from the brilliant image of the Neo - humanism in order to show the power of a people who succeeded - thanks to Tragedy - in wrestling with the terrible character of existence. It concerns a power of exceptional artistic and spiritual value that is nevertheless distorted by the modern Germans in order to raise the standard of Nazism or to throw Europe into the abyss of inhumanity.

\footnotetext{
${ }^{1}$ For the decisive role of feeling and art in the nietzschean conception of language see Thomas, Nietzsche's Tragic Regime, pp. $135-136$.
} 


\section{Conclusion}

Summarizing at this point we conclude that the nietzschean man is composed on the basis of an aim planned by life itself and fulfilled by the society, the culture and the education. An aim that draws out in the light of human consciousness all the breadth of the cosmic problematic and touches a smallest minority of individuals. It concerns individuals falling into the terror and the absurdity of existence without however, being transformed into bloody brutes. That is because their power is not arising at the point of a sword but from their ability to stand and transform the pain into representations justifying the world. In other words they embody a rare category of spiritual men who intertwines the knowledge with the risk following the nietzschean words: "I know more about life because I have so often been on the verge of losing it; and precisely therefore do I get more out of life than any of you" (Nietzsche, 2001: p. 173).

\section{References:}

1. Heilke, Thomas. (1998) Nietzsche's Tragic Regime. Illinois: Northern Illinois University Press.

2. Hillesheim, James. (1986). "Suffering and Self - Cultivation: The case of Nietzsche". Educational Theory, 36.2, pp. 171 - 178.

3. Hillesheim, James. (1990). "Nietzschean Image of Self - Overcoming". Educational Theory, 40.2, pp. $211-215$.

4. Nietzsche, Friedrich. (1966). The Birth of Tragedy and the Case of Wagner. Trans. Kaufmann, Walter. New York: Vintage.

5. Nietzsche, Friedrich. (1968). The Will to Power. Trans. Kaufmann, Walter \& Hollingdale, J. Reginald. New York: Vintage.

6. Nietzsche, Friedrich. (1990a). Twilight of the Idols / The Antichrist. Trans. Hollingdale, J. Reginald. London: Penguin Books.

7. Nietzsche, Friedrich. (1990b). "On Truth and Lies in a Nonmoral Sense". In Philosophy and truth - Selections from Nietzsche's Notedooks of the early 1870's. Trans. Breazeale, Daniel. New Jersey: Humanities Press.

8. Nietzsche, Friedrich. (1994). On the Genealogy of Morality. Trans. Diethe, Carol. Cambridge: Cambridge University Press.

9. Nietzsche, Friedrich. (1996). Human, All To Human. Trans. Hollingdale, J. Reginald. Cambridge: Cambridge University Press.

10. Nietzsche, Friedrich. (1997). Untimely Meditations. Trans. Hollingdale, J. Reginald. Cambridge: Cambridge University Press.

11. Nietzsche, Friedrich. (1998a). Philosophy in the Tragic Age of Greeks. Фrans. Cowan, Marianne. Washington: Regnery Publishing Inc.

12. Nietzsche, Friedrich. (1998b). Beyond Good and Evil. Trans. Faber, Marion. Oxford: Oxford University Press.

13. Nietzsche, Friedrich. (2001). The Gay Science. Trans. Nauckhoff, Josefine. Cambridge: Cambridge University Press.

14. Nietzsche, Friedrich. (2004). On the Future of our Educational Institutions. Фrans. Grenke, W. Michael. Indiana: St Augustine's Press. 
15. Pearson, Keith Ansell. (1994) An introduction to Nietzsche as political thinker. Cambridge: Cambridge University Press.

16. Rosenow, Eliyahu. (1989). "Nietzsche's Educational Dynamite”. Educational Theory, 39.4, pp. $307-316$.

Білл Дімопулос. Віталістичні компоненти ніцшеанської людини: суспільство, культура, освіта ${ }^{1}$

Ніцшеанська людина являє собою композицію, засновану на спробі життя визнати утаємничені в ньому самому терор, жах і абсурд. Інакше кажучи, мова йде про надзвичайно небезпечний, трагічний і в той же час невизначений запит, який задовольняється тільки за допомогою суспільства, культури і освіти. Як наслідок цієї потрійний допомоги з'являється нова категорія людини, покликаної боротися проти трагічного змісту екзистенції. Йдеться про прийдешнє покоління з «відвагою в очах», яке, однак, не має відношення до кровожерливих варварів. Це тому, що їх влада походить не від грубої сили, а від інтелектуальних здібностей терпіти і трансформувати біль в уявлення, що виправдовують світ.

Ключові слова: життя, геній, трансформація, біль, терор, суспільство, культура, освіта.

Билл Димопулос. Виталистические компоненты ницшеанского человека: общество, культура, образование

Ницшеанский человек представляет собой композицию, основанную на попытке жизни признать таящийся в ней самой террор, ужас и абсурд. Иначе говоря, речь идет о чрезвычайно опасном, трагическом и в то же время неопределенном запросе, который удовлетворяется только с помощью общества, культуры и образования. Как следствие этой тройной помощи появляется новая категория человека, призванного бороться против трагического содержания экзистенции. Речь идет о грядущем поколении с «отвагой в глазах», которое, однако, не имеет отношения к кровожадным варварам. Это потому, что его власть исходит не от грубой силы, а от интеллектуальной способности терпеть и трансформировать боль в представления, оправдывающие мир.

Ключевые слова: жмизнь, гений, трансформация, боль, террор, общество, культура, образование.

Bill Dimopoulos, PhD, Higher School of Pedagogical and Technological Education (ASPETE), Department of Patras, Greece. E-mail: billdim2000@ yahoo.gr

Білл Дімопулос, доктор філософії (PhD), Вища Школа педагогічної і технологічної освіти (ASPETE), Департамент Патрас, Греція.

\footnotetext{
${ }^{1}$ Переклад з англійської Л.Горбунової.
} 